\title{
Assessment of Genetic Variation Among Leptosphaeria maculans Isolates Using Pathogenicity Data and AFLP Analysis
}

\author{
Patchara Pongam, Department of Plant Pathology, Thomas C. Osborn, Department of Agronomy, and Paul H. \\ Williams, Department of Plant Pathology, University of Wisconsin-Madison, Madison 53706
}

\begin{abstract}
Pongam, P., Osborn, T. C., and Williams, P. H. 1999. Assessment of genetic variation among Leptosphaeria maculans isolates using pathogenicity data and AFLP analysis. Plant Dis. 83:149-154.

Increased production of rapeseed in the north central and southeastern regions of the United States has been accompanied by an increase in the incidence of blackleg disease caused by Leptosphaeria maculans. In order to assess the genetic variability and relatedness of isolates from these regions to others from around the world, we analyzed 49 aggressive isolates representing three pathogenicity groups (PG2, 3, and 4) of L. maculans from North Dakota, Georgia, Ontario, Western Canada, the United Kingdom (UK), France, Germany, and Australia using pathogenicity data and amplified fragment length polymorphism (AFLP). Approximately $10 \%$ of the 400 amplified fragments were polymorphic, scored as discrete characters and analyzed by cluster analysis. The isolates from North Dakota, Western Canada, Georgia, and PHW1252 from the UK formed one tightly clustered group and were mostly of the same pathogenicity group; whereas isolates from Ontario, Australia, France, Germany, and the remaining isolates from the UK formed a second group, which exhibited greater variation and consisted of three pathogenicity groups. The similarity between North Dakota isolates collected in 1995-96 and Western Canadian isolates collected in the 1980s suggests that L. maculans was introduced into North Dakota from Western Canada, and that the populations have remained relatively unchanged over the past 10 years.
\end{abstract}

Since the United States Food and Drug Administration granted "generally recognized as safe" status to low erucic acid rapeseed (canola) in 1985, the consumption of canola oil in the United States, imported mostly from Canada, has increased rapidly. In response to the increasing demand for edible and specialized industrial oils, rapeseed production has increased in the United States. Rapeseed is grown as a winter crop in Kentucky and neighboring states and as a spring crop in northeastern North Dakota, Minnesota, Idaho, and Montana $(5,10)$. In 1988 , there were 15,176 ha $(37,500$ acres $)$ of rapeseed in the United States, and by 1995, the area had expanded to 180,089 ha (445,000 acres). Total production reached 248 million $\mathrm{kg}$ (547 million pounds) and nearly equaled imports of 253 million $\mathrm{kg}$ (558 million pounds) (26).

Blackleg disease, caused by Leptosphaeria maculans (Desmaz.) Ces. \& De Not., anamorph Phoma lingam (Tode:Fr.) Desmaz., is a major disease of crucifers,

Corresponding author: Paul H. Williams

E-mail: phwillia@facstaff.wisc.edu

Current address of first author: Department of Plant Pathology, Faculty of Agriculture, Kasetsart University, Nakhonpathom 73140 Thailand.

Accepted for publication 27 October 1998.

Publication no. D-1998-1204-01R

(C) 1999 The American Phytopathological Society including rapeseed (Brassica napus and $B$. rapa). It is a serious concern in all countries where rapeseed is extensively grown (24). Blackleg was first reported in 1989 in approximately 100 ha representing eight fields in south central Kentucky and was responsible for yield losses of up to $80 \%$. Three isolates recovered from stubble collected from the Kentucky fields were from pathogenicity group (PG) 4 of the aggressive strain (16). During 1989 to 1991, disease surveys revealed that 13 of 37 fields, representing the bulk of rapeseed acreage in Kentucky, had blackleg. Among 38 isolates recovered from infected fields, one was classified as PG1, none as PG2, 18\% as PG3, and $79 \%$ as PG4 (5). In 1991, blackleg disease was reported in North Dakota, with the incidence ranging from 8 to $68 \%$ in the 23 fields examined. Among the isolates recovered from six fields, PG2 isolates were detected in four fields and PG1 was detected in the other two fields (11). Since PG4 is common in Europe and Australia and PG2 is common in Canada, the outbreaks in Kentucky and North Dakota are likely to have come from separate introductions of infested seeds, the former from Europe (5) and the latter from Western Canada (10).

The appearance of $L$. maculans in these two areas of the United States will have an important impact on production of this relatively new crop. Knowledge of the fungus's virulence characteristics could lead to the development of better disease management strategies. Variation in virulence is the most widely used marker for characterizing the pathogen population. However, the genes involved in host-specificity represent a small fraction of genes in the pathogen that may be subjected to host selection (12). Therefore, analysis of $L$. maculans field isolates with molecular markers may give a better measure of their genetic relatedness and origin. In this study, virulence analysis on differential $B$. napus cultivars and amplified fragment length polymorphism (AFLP) markers were used to evaluate the genetic relatedness of $L$. maculans field isolates from North Dakota with isolates from other geographical areas.

\section{MATERIALS AND METHODS}

Fungal cultures. Forty-nine isolates of L. maculans collected from rapeseed fields were used in this study (Table 1). Ten isolates from Europe and Australia were obtained from the Crucifer Genetic Cooperative $(\mathrm{CrGC}$, in the Department of Plant Pathology, University of Wisconsin-Madison) (15), and five isolates from Ontario and four isolates from Manitoba, Canada, were provided by Paul Goodwin and Roger Rimmer, respectively. Five single pycnidiospore isolates from Georgia were obtained from infected residue collected in 1993 by Curtis Hill. Twenty-five single pycnidiospore isolates from North Dakota were obtained from B. napus-infected residue collected from three commercial fields in 1995 and 1996 by Arthur Lamey. Fields were as far as $160 \mathrm{~km}$ (100 miles) apart. Isolates $21 \mathrm{~A}-\mathrm{J}$ were collected in 1995 from field 21 of the susceptible cultivar Hyola 401 with disease incidence of 90\% in Cavalier County, North Dakota. Isolates ND1-5 were collected in 1996 from a field immediately southeast of field 21 . There were three $B$. napus cultivars in this field, including Hyola 401. Isolates $75 \mathrm{~A}-\mathrm{J}$ were collected from a single field of the moderately susceptible cultivar Trojan in Bottineau County, North Dakota, with a disease incidence of $72.5 \%$.

Single pycnidiospore isolation. Small pieces of diseased stems were rinsed with water, surface-sterilized for $60 \mathrm{~s}$ in $10 \%$ commercial bleach, and rinsed. The stems were then immersed in sterile water for a few minutes, and with the aid of a dissecting microscope, single pycnidia were transferred to V8 agar plates. Cultures were grown for 7 days on V8 agar plates at 
Table 1. Leptosphaeria maculans isolates, country of origin, interaction phenotypes on cultivars Westar, Quinta, and Glacier, and pathogenicity grouping

\begin{tabular}{|c|c|c|c|c|c|c|}
\hline Isolates $^{a}$ & Origin $^{b}$ & Westar & Quinta & Glacier & $\mathbf{P G}^{\mathrm{c}}$ & AFLPd \\
\hline $21 \mathrm{~A}$ & ND & + & I & - & 2 & + \\
\hline $21 \mathrm{~B}$ & ND & + & I & - & 2 & + \\
\hline $21 \mathrm{C}$ & ND & + & I & - & 2 & + \\
\hline $21 \mathrm{D}$ & ND & + & I & - & 2 & + \\
\hline $21 \mathrm{E}$ & ND & + & I & - & 2 & + \\
\hline $21 \mathrm{~F}$ & ND & + & I & - & 2 & + \\
\hline $21 \mathrm{G}$ & ND & + & I & - & 2 & + \\
\hline $21 \mathrm{H}$ & ND & + & I & - & 2 & + \\
\hline $21 \mathrm{I}$ & ND & + & I & - & 2 & + \\
\hline $21 \mathrm{~J}$ & ND & + & I & - & 2 & + \\
\hline $75 \mathrm{~A}$ & ND & + & I & - & 2 & + \\
\hline $75 B$ & ND & + & I & - & 2 & + \\
\hline $75 \mathrm{C}$ & ND & + & I & - & 2 & + \\
\hline $75 \mathrm{D}$ & ND & + & I & - & 2 & + \\
\hline $75 E$ & ND & + & I & - & 2 & + \\
\hline $75 \mathrm{~F}$ & ND & + & I & - & 2 & + \\
\hline $75 \mathrm{G}$ & ND & + & I & - & 2 & + \\
\hline $75 \mathrm{H}$ & ND & + & I & - & 2 & + \\
\hline $75 \mathrm{I}$ & ND & + & I & - & 2 & + \\
\hline $75 \mathrm{~J}$ & ND & + & I & - & 2 & + \\
\hline ND1 & ND & + & I & - & 2 & - \\
\hline ND2 & ND & + & I & - & 2 & - \\
\hline ND3 & ND & + & I & - & 2 & - \\
\hline ND4 & ND & + & I & - & 2 & - \\
\hline ND5 & ND & + & I & - & 2 & - \\
\hline IIA & Georgia & + & I & - & 2 & + \\
\hline IIB & Georgia & + & - & I & $?$ & + \\
\hline IIC1 & Georgia & + & I & - & 2 & + \\
\hline IIC2 & Georgia & + & I & - & 2 & + \\
\hline IID & Georgia & + & - & I & $?$ & + \\
\hline PHW1223 & Australia & + & + & + & 4 & + \\
\hline PHW1227 & Australia & + & + & + & 4 & + \\
\hline PHW1230 & Germany & + & I & + & 3 & + \\
\hline PHW1236 & Germany & + & I & + & 3 & + \\
\hline PHW1237 & Germany & + & I & + & 3 & + \\
\hline PHW1244 & France & + & I & + & 3 & + \\
\hline PHW1245 & France & + & I & - & 2 & + \\
\hline PHW1246 & UK & + & I & - & 2 & + \\
\hline PHW1251 & UK & + & + & + & 4 & + \\
\hline PHW1252 & UK & + & I & - & 2 & + \\
\hline $85-7$ & Manitoba & + & I & - & 2 & + \\
\hline $86-15$ & Manitoba & + & I & - & 2 & + \\
\hline $87-15$ & Manitoba & + & I & - & 2 & + \\
\hline $87-21$ & Manitoba & + & I & - & 2 & + \\
\hline $2 \mathrm{~A} 1$ & Ontario & nd & nd & nd & nd & + \\
\hline $2 \mathrm{~A} 2$ & Ontario & nd & nd & nd & nd & + \\
\hline $2 \mathrm{C} 3$ & Ontario & nd & nd & nd & nd & + \\
\hline $2 \mathrm{C} 4$ & Ontario & nd & nd & nd & nd & + \\
\hline 2L6 & Ontario & nd & nd & nd & nd & + \\
\hline
\end{tabular}

a All isolates are from Brassica napus host except PHW1245, which is from B. oleracea.

${ }^{b}$ ND, North Dakota isolates obtained from Arthur Lamey; Georgia, isolates from Curtis Hill; Australia, Germany, France, and the UK, isolates from Crucifer Genetic Cooperative, University of Wisconsin-Madison; Manitoba, isolates from Roger Rimmer; Ontario, isolates from Paul Goodwin.

${ }^{c}$ Pathogenicity grouping (PG) based on interaction phenotypes on three differential cultivars $(+=$ virulent, $-=$ avirulent, $\mathrm{I}=$ intermediate); ? = undesignated; $\mathrm{nd}=$ not determined.

${ }^{\mathrm{d}}+=$ included in amplified fragment length polymorphism (AFLP) analysis; $-=$ not included in AFLP analysis.

Table 2. Sequence of HindIII and MseI amplification primers used in amplified fragment length polymorphism (AFLP) analysis

\begin{tabular}{llc}
\hline Primer & \multicolumn{1}{c}{ Sequence } & No. of bands $^{\mathbf{a}}$ \\
\hline Hind-AC & 5' GACTGCGTACCAGCTT-AC 3' & - \\
Mse-CAA & 5' GATGAGTCCTGAGTAA-CAA 3' & 7 \\
Mse-CAG & 5' GATGAGTCCTGAGTAA-CAG 3' & 8 \\
Mse-CAC & 5' GATGAGTCCTGAGTAA-CAC 3' & 8 \\
Mse-CAT & 5' GATGAGTCCTGAGTAA-CAT 3' & 9 \\
Mse-TCC & 5' GATGAGTCCTGAGTAA-TCC 3' & 3 \\
Mse-GAG & 5' GATGAGTCCTGAGTAA-GAG 3' & 4 \\
\hline
\end{tabular}

${ }^{a}$ Number of polymorphic bands detected among Leptosphaeria maculans isolates. $24^{\circ} \mathrm{C}$ and irradiated under continuous coolwhite fluorescent light (100 to $150 \mu \mathrm{E} \mathrm{s} \mathrm{s}^{-1}$ $\mathrm{m}^{-2}$ ) to induce pycnidia formation. Water suspensions of pycnidiospores were diluted to a concentration of $10^{3}$ to $10^{4}$ spores per $\mathrm{ml}$. One hundred $\mu \mathrm{l}$ of the pycnidiospore suspension was spread on $2 \%$ water plates, and after 2 days of incubation at room temperature, single germinating pycnidiospores were transferred to V8 agar and maintained under the conditions described above.

Inoculum preparation and pathogenicity tests. Thirty single pycnidiospore isolates from infected residue collected in North Dakota and five from Georgia were tested on B. napus cvs. Westar, Quinta, and Glacier to determine their PG. Inoculum preparation and pathogenicity tests were performed as previously described (14).

DNA preparation. Forty-four of the 49 L. maculans isolates were selected for AFLP analysis (Table 1). Isolates were grown in Czapek's medium supplemented with $0.2 \%$ yeast extract with agitation at room temperature for 2 to 5 days. Mycelia were harvested by vacuum filtration through Whatman no. 1 filter paper and rinsed with sterile water, then kept at $-80^{\circ} \mathrm{C}$ for several hours and lyophilized. Two hundred $\mathrm{mg}$ of freeze-dried mycelia was ground in liquid nitrogen, using a mortar and pestle, and suspended in $4 \mathrm{ml}$ of extraction buffer $(50 \mathrm{mM}$ Tris- $\mathrm{HCl}[\mathrm{pH}$ 8.0], $850 \mathrm{mM} \mathrm{NaCl}, 100 \mathrm{mM}$ EDTA, $1 \%$ sodium dodecyl sulfate [SDS]) and $0.4 \mathrm{ml}$ of $10 \%$ (wt/vol) CTAB (in $0.7 \mathrm{M} \mathrm{NaCl}$ ). After incubation at $65^{\circ} \mathrm{C}$ for $15 \mathrm{~min}$, the mixture was extracted with one volume of phenol:chloroform:isoamyl alcohol $(25: 24: 1)$ and then with one volume of chloroform:isoamyl alcohol (24:1). The DNA was then precipitated with two volumes of ice-cold $100 \%$ ethanol, washed with $70 \%$ ethanol, and suspended in $1 \mathrm{ml}$ of $\mathrm{TE}$ buffer (10 mM Tris- $\mathrm{HCl}$ [pH 8.0], $1 \mathrm{mM}$ EDTA). All DNA extracts were quantified by fluorometry and adjusted to a final concentration of $30 \mathrm{ng} / \mu \mathrm{l}$ for AFLP analysis.

AFLP analysis. Restriction, ligation, amplification, and gel analysis were performed as described (27). The minor modification was that the primer pair used in the first amplification complementary to adapter sequence had one additional nucleotide at $3^{\prime}$ end. The sequence of the HindIII adapter was:

\section{5' CTCGTAGACTGCGTACC 3' CATCTGACGCATGGTCGA}

The sequence of the MseI adapter was: 5' GACGATGAGTCCTGAG 3' TACTCAGGACTCAT

Genomic DNA $(0.5 \mu \mathrm{g})$ was incubated for $1 \mathrm{~h}$ at $37^{\circ} \mathrm{C}$ with $5 \mathrm{U}$ each of HindIII and $\mathrm{Mse}$ I restriction enzymes in $40 \mu \mathrm{l}$ of reaction mixture $(20 \mathrm{mM}$ Tris-HAc $[\mathrm{pH}$ 7.9], $10 \mathrm{mM} \mathrm{MgAc}, 50 \mathrm{mM}$ KAc, $1 \mathrm{mM}$ DTT). These DNA fragments were then 


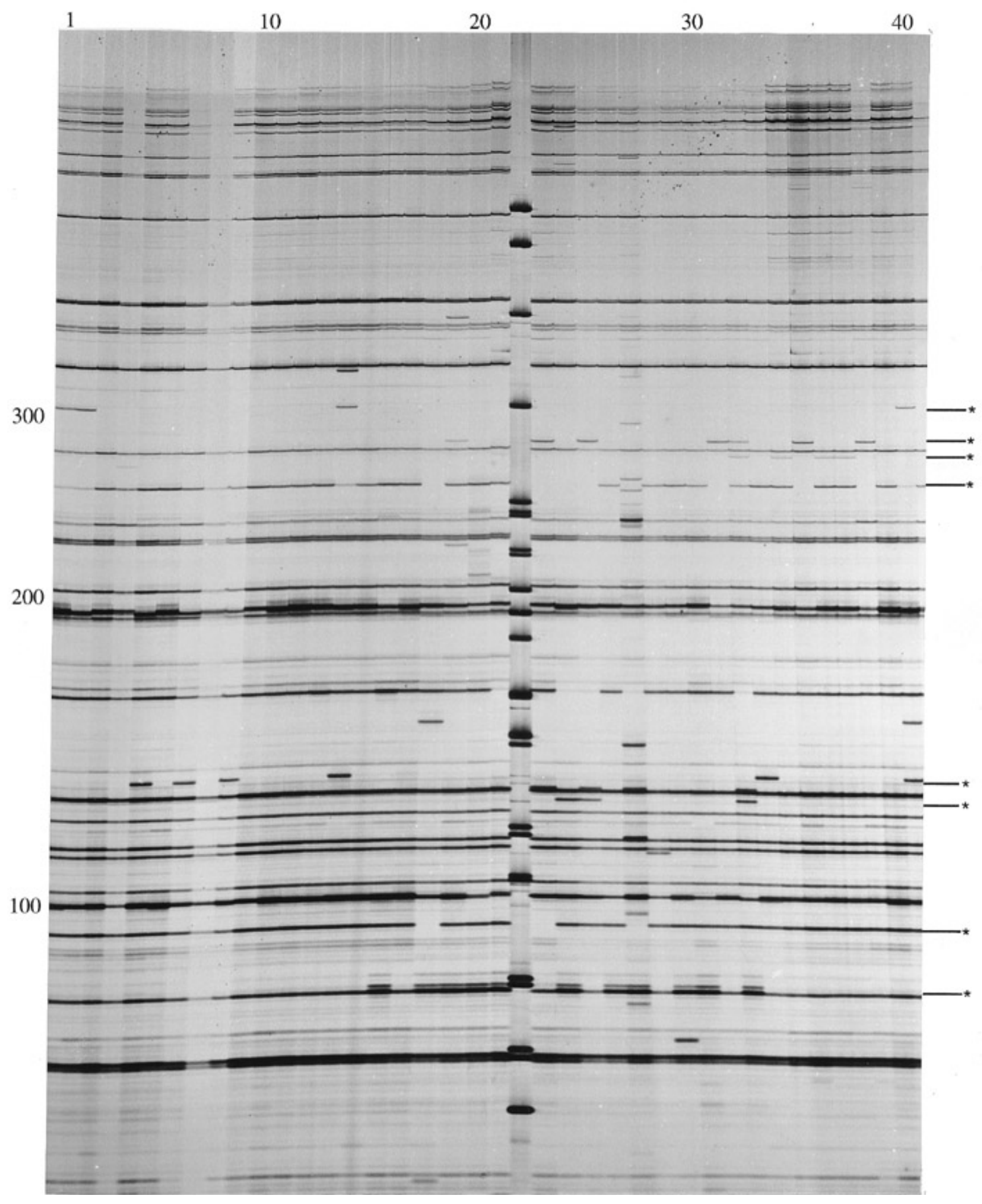

Fig. 1. Amplified fragment length polymorphism (AFLP) fingerprints of Leptosphaeria maculans isolates after second amplification with primer combination Hind-AC/Mse-CAT. Scored polymorphic markers are indicated as marks $\left(^{*}\right)$. Molecular weight markers (lane 22) are indicated in base pairs. Lanes 1 to 7 are isolates 21D-J; lanes 8 to 17 are isolates 75A-J from North Dakota encoded in Table 1; lanes 18 to 21 and 23 are isolates from Ontario 2A1, 2A2, 2C3, 2C4, and 2L6; lanes 24 to 33 are isolates from Crucifer Genetic Cooperative, University of Wisconsin-Madison, encoded in Table 1; lanes 34 to 38 are isolates from Georgia, encoded in Table 1; lanes 39 to 41 are isolates from Western Canada 86-9, 86-21, and 87-15, respectively. 
ligated with the adapters by adding $10 \mu \mathrm{l}$ of ligation mixture $(5 \mathrm{pMol}$ HindIII adapter, $50 \mathrm{pMol}$ MseI adapter, 1 U T4 DNA Ligase, $0.2 \mathrm{mM}$ ATP, $20 \mathrm{mM}$ Tris-HAc [pH 7.9], 10 $\mathrm{mM} \mathrm{MgAc}, 50 \mathrm{mM} \mathrm{KAc}, 1 \mathrm{mM}$ DTT) to the restriction mixture and continuing the incubation for another $3 \mathrm{~h}$ at $37^{\circ} \mathrm{C}$. After ligation, the reaction mixture was diluted 10 fold with TE buffer and stored at $-20^{\circ} \mathrm{C}$. These ligated fragments served as templates in the amplification reaction.

The first amplification reaction was performed in $20 \mu \mathrm{l}$ reaction $(5 \mu \mathrm{l}$ DNA, $50 \mathrm{ng}$ each of primers, $0.08 \mathrm{U}$ of Taq polymerase [Perkin Elmer, Norwalk, CT], $100 \mathrm{mM}$ Tris- $\mathrm{HCl}$ [pH 8.3], $500 \mathrm{mM} \mathrm{KCl,} 15 \mathrm{mM}$ $\mathrm{MgCl}_{2}, 0.01 \%$ [wt/vol] gelatin, $0.2 \mathrm{mM}$ each dNTPs) using the following temperature profile: $30 \mathrm{~s}$ at $94^{\circ} \mathrm{C} ; 30 \mathrm{~s}$ at $60^{\circ} \mathrm{C}$; $60 \mathrm{~s}$ at $72^{\circ} \mathrm{C}$ for 20 cycles. The amplification product was diluted 10-fold with TE buffer and used as templates in the second amplification. The second amplification was performed using primers derived from the first set of primers with additional nucleotides at the $3^{\prime}$ end (Table 2). The $H$ indIII primer was labeled using $100 \mu \mathrm{Ci}$ $\left[\gamma_{-}{ }^{33} \mathrm{P}\right]$ ATP and $0.2 \mathrm{U}$ of $\mathrm{T} 4$ kinase. Amplification was performed using $5 \mathrm{ng}$ of labeled primer and $50 \mathrm{ng}$ of $\mathrm{Mse}$ I primer in the reaction mixture described above. The following temperature profile was used: 12 cycles of $30 \mathrm{~s}$ at $94^{\circ} \mathrm{C} ; 30 \mathrm{~s}$ at $65^{\circ} \mathrm{C} ; 60 \mathrm{~s}$ at $72^{\circ} \mathrm{C}$, where the annealing temperature was subsequently reduced by $0.7^{\circ} \mathrm{C}$ each cycle. The amplification was continued for 23 cycles of $30 \mathrm{~s}$ at $94^{\circ} \mathrm{C}, 30 \mathrm{~s}$ at $56^{\circ} \mathrm{C}$, and $60 \mathrm{~s}$ at $72^{\circ} \mathrm{C}$. All amplification reactions were performed in a PE-9600 thermocycler (Perkin Elmer). Reaction products were analyzed by electrophoresis in a $5 \%$ denaturing acrylamide gel at the constant power of $45 \mathrm{~W}$ for $3 \mathrm{~h}$. The gels were fixed for 30 min in $10 \%$ acetic acid, dried on the gel plate, and exposed to X-ray films at room temperature.

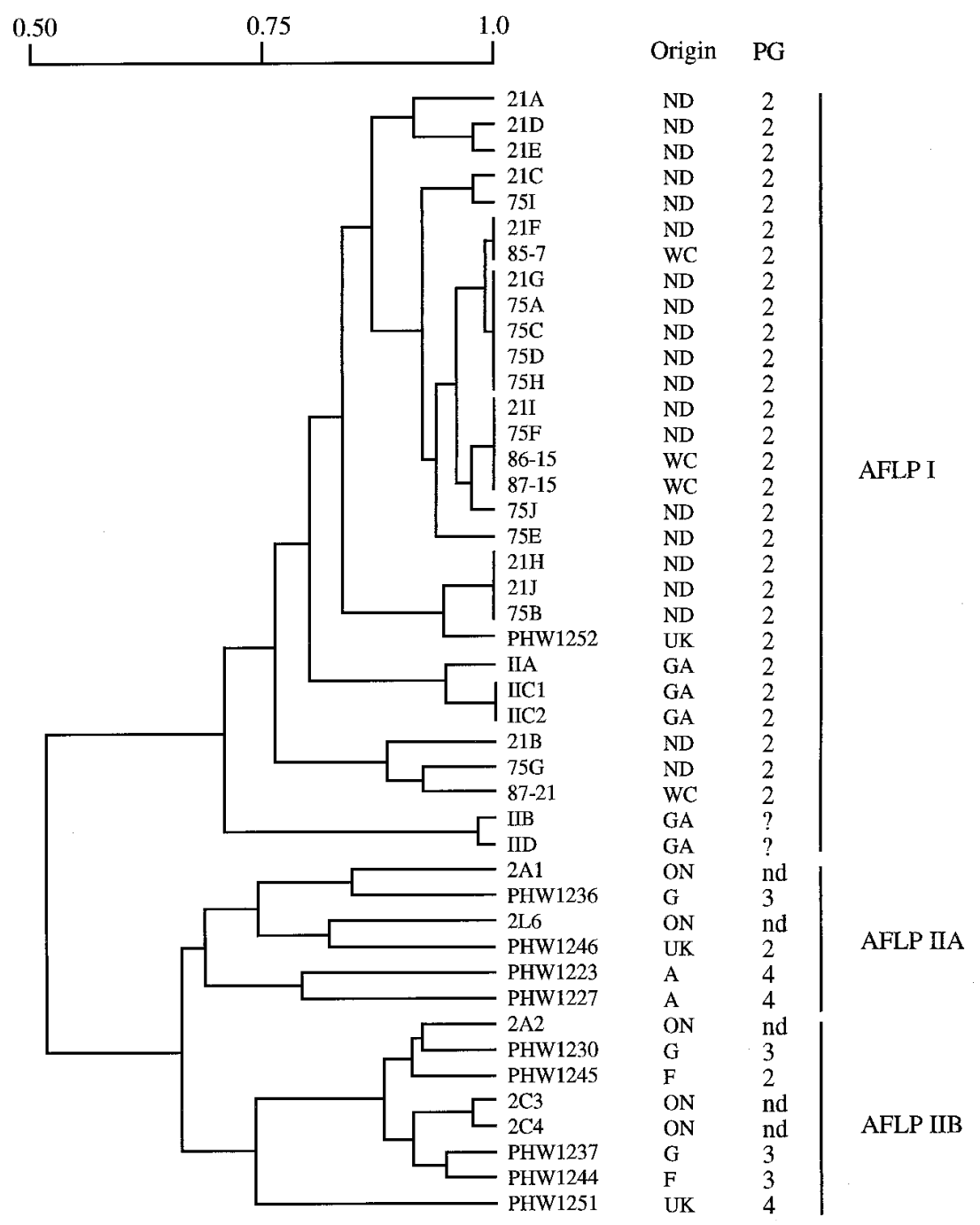

Fig. 2. Dendrogram generated from cluster analysis of 44 Leptosphaeria maculans isolates using simple matching similarity coefficients. Origin denotes location of $L$. maculans isolation with $\mathrm{ND}=$ North Dakota, GA = Georgia, WC $=$ Western Canada, ON = Ontario, A = Australia, G = Germany, $\mathrm{UK}=$ United Kingdom, and $\mathrm{F}=$ France $. \mathrm{PG}=$ pathogenicity grouping based on interaction phenotypes on the three differential cultivars as shown in Table 1 , with ? = undesignated and nd = not determined.
Data analysis. Each polymorphic AFLP fragment was treated as a unit character and scored as presence (1) or absence (0) across all isolates. The experiments were repeated, and only reproducible bands were scored. The relationships among isolates were analyzed by phenetic (cluster) analysis using computer software package NTSYS 1.8 (23). In the cluster analysis, the binary matrix was used to construct a matrix of similarities between all pairs of isolates based on Simple Matching (SM) and Dice similarity coefficients using the SIMQUAL program. The unweighted paired group method using arithmetic means (UPGMA) was used to construct dendrograms by the SAHN clustering program. Dendrograms were generated using the TREE program.

\section{RESULTS}

Pathogenicity tests. Pathogenicity data for 25 isolates from North Dakota and five isolates from Georgia based on cotyledon reactions on B. napus cvs. Westar, Quinta, and Glacier are presented in Table 1. All isolates tested produced a typical susceptible reaction on the cotyledons of $B$. napus cv. Westar, which appeared as large areas of gray-green collapsed tissue with abundant pycnidia (IP 8-9), indicating that they are all of the aggressive strain. The 25 isolates from North Dakota produced intermediate interaction phenotypes (IP 4-6) on Quinta and were avirulent (IP 1-3) on Glacier (Table 1), indicating they conform to PG2. Three isolates from Georgia, IIA, IIC1, and IIC2, were also classified as PG2. The other two isolates, IIB and IID, produced an intermediate IP on Glacier (IP 5-6) and were avirulent (IP 1-3) on Quinta (Table 1), and as such did not belong to any of the pathogenicity groups previously defined by the differentials Westar, Quinta, and Glacier $(7,14)$.

AFLP analysis. AFLP fingerprints of the L. maculans isolates revealed clearly detected polymorphisms (Fig. 1). The experiments were performed twice, and the polymorphic DNA fragments detected were identical. The number of amplified fragments ranged from 60 to 80 for the six primer combinations, and the size of the DNA fragments ranged from 50 to $600 \mathrm{bp}$. Among these amplified fragments, 39 polymorphic DNA fragments were scored as discrete character data (presenceabsence). The combined character data matrix was analyzed based on the assumption that co-migrating bands in an AFLP gel are homologous.

The 44 isolates were clustered as two distinct groups (AFLP I and AFLP II) using UPGMA with the SM coefficient (Fig. 2). AFLP I contained all isolates from North Dakota, Georgia, and Western Canada, and PHW1252 from the UK. Two of the isolates from Georgia, IIB and IID, were located further from the rest of the group at a similarity level below $75 \%$. All 
isolates in this group belong to PG2 except the two Georgia isolates, which have unassigned pathogenicity. The AFLP II group included all isolates from Ontario, Australia, France, Germany, and the remaining isolates from the UK. Isolates in AFLP II were clustered more loosely and were further divided below the $75 \%$ similarity level into two subgroups, AFLP IIA and AFLP IIB. In AFLP IIA, isolates PHW1223 and PHW1227, which belong to PG4 from Australia, clustered together and were relatively farther from the rest in the subgroup. In AFLP IIB, isolate PHW1251 from the UK was placed relatively farther from the three Ontario isolates and from the French and German isolates. The dendrogram generated via the Dice similarity coefficient was topologically similar to that obtained from the SM coefficient (data not shown).

\section{DISCUSSION}

Based on pathogenicity data, all isolates from North Dakota were classified as PG2. Three of five Georgia isolates also belong to PG2. The other two isolates did not belong to any previously described pathogenicity grouping. Previous study of $L$. maculans isolates in Kentucky revealed that PG3 and PG4 were predominant (5). The absence of PG3 and PG4 isolates from Georgia may be due to the small sample of the population surveyed. Although some isolates from Georgia may be related to those found in North Dakota, the Georgia population was more variable.

The absence of observed variation in pathogenicity among North Dakota isolates suggests that the L. maculans population in that state is relatively homogeneous. Previous studies have identified more variation in pathogenicity when a wider set of genetic differential host lines was used $(2,8,9)$. A general lack of standardization of differentials, the heterogeneous consistency of lines, and the unknown genetic control of the resistance in the differentiating hosts together with variation in procedures for evaluating pathogenicity have complicated the interpretation and comparisons between pathogenicity studies (22). There is a substantial need for the development of genetically defined differentials, such as near-isogenic lines with single resistance gene differences.

The pathogenicity data alone may not reflect the true genetic variability and evolutionary history of the isolates studied. For example, isolates that are genetically distinct may have similar or identical pathogenicity patterns because they have been subjected to the same selection pressure by a common set of hosts. Molecular markers that are selectively neutral and randomly distributed in the genome can provide additional useful information on genetic variation and origin of isolates in a new crop production area. DNA marker technologies have been used to distinguish between aggressive and nonaggressive strains of $L$. maculans $(3,6,7,17,18,20,25,28)$. Previous phylogeny based on restriction fragment length polymorphisms led to grouping of aggressive isolates into more closely related phylogenetic groups (7).

This study showed that the AFLP technique is useful for the characterization of intraspecific variation among $L$. maculans populations. Small amounts of genomic DNA (50 ng) were sufficient as templates for an unlimited amplification of restriction fragments. Six primer combinations enabled the amplification of 400 fragments, of which $10 \%$ were polymorphic. The AFLP approach is objective, repeatable, and unaffected by environmental factors, and it provides a direct assessment of the genetic relationships of the fungus at the DNA level. The data generated are amenable to mathematically robust phylogeny reconstruction.

In cluster analysis, all North Dakota and Western Canadian isolates formed a distinct and rather uniformly clustered group supporting the hypothesis that L. maculans was introduced into North Dakota from Western Canada. This is likely because seeds planted in North Dakota have been imported from Western Canada. Isolate PHW1252, collected in the UK, was also placed in PG2, suggesting that it may be a possible ancestor of the Western Canadian isolates or vice versa.

Pathogenicity and cluster analysis of the Georgia isolates revealed considerable variation among isolates. It is interesting to note that some of the Georgia isolates were closely related to North Dakota and Western Canadian isolates. In spite of the small number of Georgia isolates analyzed, there was more variation observed among these isolates. Further research on the genetic relatedness of more isolates of $L$. maculans from the southeastern United States with isolates from the northern plains will provide information of use for disease management of rapeseed production in the United States.

In Canada, the aggressive isolates were first reported in Saskatchewan in 1975 (19), and the incidence increased 10-fold between 1978 and 1981 (21). Aggressive isolates were first detected in Alberta in 1983 and in Ontario in $1986(1,19,21)$. Previous studies revealed relatively high similarity coefficients and the same glucose phosphate isomerase isozyme patterns among isolates studied from Western Canada and Ontario $(3,19)$. Recently, variation in pathogenicity and random amplified polymorphic DNA (RAPD) patterns of $L$. maculans isolates within and between oilseed rape fields in southern Ontario has been reported. Eighty percent of the isolates studied were in PG4, and $11 \%$ were in PG3. The remaining 9\% were assigned to the new PG5 based on intermediate reaction on the three differential cultivars.
In RAPD analysis, there was no two isolates that had identical patterns, suggesting that the populations of the fungus were produced mostly by sexual reproduction. Cluster analysis using RAPD patterns grouped isolates into two populations corresponding to the field of collection (13). In this study, Ontario isolates were clustered with isolates from Europe and were distinct from Western Canada and North Dakota isolates, all of which belong to PG2. A relatively high number of AFLP markers from this study revealed genetic variation between Western Canadian and Ontario isolates, suggesting the possibility that $L$. maculans was introduced into different regions of Canada from different source populations rather than having originated from a common Canadian ancestor, as previous studies have suggested $(3,19)$.

\section{ACKNOWLEDGMENTS}

We thank Arthur Lamey, Curtis Hill, Roger Rimmer, and Paul Goodwin for providing fungal isolates and Yan-San Chyi and Manju Gupta at Mycogen Plant Sciences, Inc., Indianapolis, IN, for assistance with AFLP analysis.

\section{LITERATURE CITED}

1. Anonymous. 1990. Blackleg of canola. Alberta Agriculture, Agri-Fax, Edmonton, Alberta, Canada.

2. Badawy, H. M. A., Hoppe, H. H., and Koch, E. 1991. Differential reactions between the genus Brassica and aggressive single spore isolates of Leptosphaeria maculans. J. Phytopathol. 131:109-119.

3. Goodwin, P. H., and Annis, S. L. 1991. Rapid identification of genetic variation and pathotype of Leptosphaeria maculans by random amplified polymorphic DNA assay. Appl. Environ. Microbiol. 57:2482-2486.

4. Gugel, R. K., and Petrie, G. A. 1992. History, occurrence, impact, and control of blackleg of rapeseed. Can. J. Plant Pathol. 14:36-45.

5. Hershman, D. E., and Perkins, D. M. 1995 Etiology of canola blackleg in Kentucky and seasonal discharge patterns of Leptosphaeria maculans ascospores from infested canola stubble. Plant Dis. 79:1225-1229.

6. Johnson, R. D., and Lewis, B. G. 1990 DNA polymorphism in Leptosphaeria maculans. Physiol. Mol. Plant Pathol. 37:417-424.

7. Koch, E., Song, K., Osborn, T. C., and Williams, P. H. 1991. Relationship between pathogenicity and phylogeny based on restriction fragment length polymorphism in Leptosphaeria maculans. Mol. Plant-Microbe Interact. 4:341-349.

8. Kuswinanti, T., Sock, J., and Hoppe, H. H. 1995. Variation in virulence of aggressive isolates of Leptosphaeria maculans based on cotyledons reactions on an extended differential set. Pages 1248-1250 in: Proc. Int. Rapeseed Congr., 9th. Henry Ling, Ltd., Dorchester, UK.

9. Kutcher, H. R., van den Berg, C. G. J., and Rimmer, S. R. 1993. Variation in pathogenicity of Leptosphaeria maculans on Brassica spp. based on cotyledon and stem reactions. Can. J. Plant Pathol. 15:253-258.

10. Lamey, H. A. 1995. Survey of blackleg and Sclerotinia stem rot of canola in North Dakota in 1991 and 1993. Plant Dis. 79:322-324.

11. Lamey, H. A., and Hershman, D. E. 1993. Blackleg of canola (Brassica napus) caused by Leptosphaeria maculans in North Dakota. 
Plant Dis. 77:1263.

12. Leung, H., Nelson, R. J., and Leach, J. E. 1993. Population structure of plant pathogenic fungi and bacteria. Adv. Plant Pathol. 10:157-205.

13. Mahuku, G. S., Goodwin, P. H., Hall, R., and Hsiang, T. 1997. Variability in the highly virulent type of Leptosphaeria maculans within and between oilseed rape fields. Can. J. Bot. 75:1485-1492.

14. Mengistu, A., Rimmer, S. R., Koch, E., and Williams, P. H. 1991. Pathogenicity grouping of isolates of Leptosphaeria maculans on Brassica napus cultivars and their disease reaction profiles on rapid-cycling brassicas. Plant Dis. 75:1279-1282.

15. Mengistu, A., Rimmer, R. S., and Williams, P. H. 1993. Protocols for in vitro sporulation, ascospore release, sexual mating, and fertility in crosses of Leptosphaeria maculans. Plant Dis. 77:538-540

16. Mengistu, A., Williams, P. H., Hershman, D. E., and Sippell, D. W. 1990. Black leg of canola (Brassica napus var. oleifera) in Kentucky. Plant Dis. 74:938.

17. Meyer, W., Lieckfeldt, E., Wöstemeyer, J., and Börner, T. H. 1992. DNA fingerprinting for differentiating aggressivity groups of the rape seed pathogen Leptosphaeria maculans. Mycol. Res. 96:651-657.

18. Morales, V. M., Pelcher, L. E., and Taylor, J. L. 1993. Comparison of the 5.8s rDNA and internal transcribed spacer sequences of isolates of Leptosphaeria maculans from different pathogenicity groups. Curr. Genet. 23:490-495.

19. Peters, R., and Hall, R. 1989. Differentiation of strains of Leptosphaeria maculans from rapeseed in Ontario. Can. J. Plant Pathol. 11:197.

20. Petrie, G. A. 1978. The rapid differentiation of virulent and weakly virulent strains of Leptosphaeria maculans (blackleg or stem canker) and related pycnidial fungi from Brassica seeds and stems. Can. J. Plant Pathol. 10:188-190.

21. Petrie, G. A., Mortensen, K., and Dueck, J. 1985. Blackleg and other diseases of rapeseed in Saskatchewan, 1978 to 1981. Can. Plant Dis. Surv. 65:35-41.

22. Rimmer, S. R., and van den Berg, C. G. J. 1992. Resistance of oilseed Brassica spp. to blackleg caused by Leptosphaeria maculans. Can. J. Plant Pathol. 14:56-66.

23. Rohlf, F. J. 1993. NTSYS-pc Numerical Taxonomy and Multivariate Analysis System.
Ver. 1.8. Applied Biostatistics Inc., New York.

24. Salisbury, P. A., Ballinger, D. J., Wratten, N. Plummer, K. M., and Howlett, B. J. 1995. Blackleg disease on oilseed Brassica in Australia: A review. Aust. J. Exp. Agric. 35:665672.

25. Schäfer, C., and Wöstemeyer, J. 1992. Random primer dependent PCR differentiates aggressive from non-aggressive isolates of the oilseed rape pathogen Phoma lingam (Leptosphaeria maculans). J. Phytopathol. 136:124-136.

26. U.S. Dep. Agric. Energy Res. Serv. 1996. Oil Crops Yearbook. U.S. Dep. Agric. Energy Res. Serv.

27. Vos, P., Hogers, R., Bleeker, M., Reijans, M., van de Lee, T., Hornes, M., Frijters, A., Pot, J., Peleman, J., Kuiper, M., and Zabeau, M 1995. AFLP: A new technique for DNA fingerprinting. Nucleic Acids Res. 23:44074414.

28. Xue, B., Goodwin, P. H., and Annis, S. L. 1992. Pathotype identification of Leptosphaeria maculans with PCR and oligonucleotide primers from ribosomal internal transcribed spacer sequences. Physiol. Mol. Plant Pathol. 41:179-188. 